\title{
Comparison of the Haematological and Anaesthetic Complications of Multiple Pregnancy Cases
}

\section{Çoğul Gebelik Olgularının Hematolojik ve Anestezik Komplikasyonlarının Karşılaştırılması}

\author{
(1) Berna Şermin Kılıç1, (1) Nil Atakul11, (1) Ayşe Gül Ferlengez²
}

1 University of Health Sciences Turkey, İstanbul Training and Research Hospital, Clinic of Gynecology and Obstetrics, istanbul, Turkey

2University of Health Sciences Turkey, İstanbul Training and Research Hospital, Clinic of Anesthesia and Reanimation, İstanbul, Turkey

\begin{abstract}
Introduction: The frequency of caesarean delivery is increasing worldwide. Nowadays, multiple pregnancy rates are increasing significantly due to the prevalence of assisted reproductive techniques. The purpose of this retrospective study is to compare the haematological and anaesthesia complications of multiple and singleton pregnancies and to increase awareness among anaesthesiologists and obstetricians of complications that may occur during and after a caesarean section in multiple pregnancies.
\end{abstract}

Methods: Our study was carried out by retrospectively searching the anaesthesia forms and files of the American Society of Anesthesiology 1-2 group of patients, who underwent caesarean sections between January 2019 and January 2020 at the University of Health Sciences Turkey, İstanbul Training and Research Hospital Gynecology and Obstetrics Clinic. The cases were then divided into multiple $(n=50)$ and singleton $(n=63)$ pregnancies, and the haematological and anaesthesia complications were compared between the two groups.

Results: No statistically significant difference was found between the age, pre- and postoperative haematocrit (Hct) values, and Hct differences between singleton and twin pregnancies $(p>0.05)$. The rate of bradycardia in twin pregnancies was found to be significantly lower than that in singleton pregnancies $(p<0.05)$. There was no statistically significant difference in nausea-vomiting and hypotension rates between twin and singleton pregnancies $(p=0.26)$.

Conclusion: Knowledge about complications associated with anaesthesia in patients with multiple pregnancies delivering by caesarean section in the world and our country is still insufficient. Based on our data, we recommend that anaesthesiologists and obstetricians work as a team and prepare for the operation in a planned approach, considering the hemodynamic changes occurring owing to twin pregnancies.

Keywords: Multiple pregnancy, spinal anaesthesia, hypotension, bradycardia, haematocrit

\section{öz}

Amaç: Sezaryen doğum sıklığı dünya çapında giderek artmaktadır. Günümüzde, yardımcı üreme tekniklerinin yaygınlığından dolayı çoğul gebelik oranları önemli ölçüde artmaktadır. Bu retrospektif çalıșmanın amacı çoğul ve tekil gebeliklerde hematoloji ve anestezi komplikasyonlarını retrospektif olarak karșılaștırmak ve anestezi ve kadın doğum hekimlerinin ikiz gebeliklerde sezaryen sırası ve sonrasında oluşabilecek komplikasyonları ile ilgili farkındalıklarını artırmaktır.

Yöntemler: Çalıșmamız Sağlık Bilimleri Üniversitesi, İstanbul Eğitim ve Araștırma Hastanesi Kadın Hastalıkları ve Doğum Kliniği'nde, Ocak 2019 ve Ocak 2020 tarihleri arasında 18-45 yaș arası sezaryen operasyonu yapılan Amerikan Anesteziyoloji Derneği 1-2 grubuna giren hastaların anestezi formları ve dosyaları retrospektif taranarak gerçekleștirilmiştir. Olgular daha sonra çoğul $(n=50)$ ve tekil $(n=63)$ gebelik olarak ikiye ayrılarak gruplar arası hematolojik ve anestezi komplikasyonları karşılaștırılmıștır.

Bulgular: Tekiz ve ikiz gebeliklerde yaş, operasyon öncesi ve sonrası hematokrit (Hct) değerleri, Hct farkları arasında istatistiksel anlamlı fark bulunamamıştır $(p>0,05)$. I ikiz gebeliklerde bradikardi oranı tekiz gebeliklere göre istatistik anlamlı olarak düșük bulunmuştur $(p<0,05)$. Ikiz ve tekiz gebeliklerde bulantı-kusma ve hipotansiyon oranları arasında fark bulunmamıștır ( $p=0,26)$.

Sonuç: Türkiye'de ve dünyada sezaryen ile doğum yapılan çoğul gebelik hastalarında anestezi ile ilișkili komplikasyon görülme sıklığı ile ilgili çalışmalar halen yetersizdir. Verilerimizden yola çıkarak anestezi ve kadın doğum doktorlarının ekip olarak çalışması ve ikiz gebeliklere bağlı hemodinamik değişiklikleri göz önünde bulundurarak planlı ve hazır bir şekilde operasyon hazırlığı yapmalarını önermekteyiz.

Anahtar Kelimeler: Çoğul gebelik, spinal anestezi, hipotansiyon, bradikardi, hematokrit
Address for Correspondence/Yazıșma Adresi: Berna Șermin Kılıç MD, University of Health Sciences Turkey, İstanbul Training and Research Hospital, Clinic of Gynecology and Obstetrics, İstanbul, Turkey

Phone: +90 5056368947 E-mail: berna_doctor@hotmail.com ORCID ID: orcid.org/0000-0002-0103-0709

Cite this article as/Atıf: Kılıç BŞ, Atakul N, Ferlengez AG. Comparison of the Haematological and Anaesthetic Complications of Multiple Pregnancy Cases. İstanbul Med J 2020; 21(6): 418-422.
Received/Geliș Tarihi: 06.06.2020 Accepted/Kabul Tarihi: 20.08.2020

(C) Copyright 2020 by the University of Health Sciences Turkey, Istanbul Training and Research Hospital/istanbul Medical Journal published by Galenos Publishing House.

(c) Telif Hakkı 2020 Sağılk Bilimleri Üniversitesi Istanbul Ĕğitim ve Araştırma Hastanesi/Istanbul Tıp Dergisi, Galenos Yayınevi tarafından basılmıștır. 


\section{Introduction}

The frequency of cesarean delivery is steadily increasing worldwide (1). Although cesarean section has become very safe over the years, it is still associated with high maternal and perinatal mortality and morbidity rates (2).

Selection of anesthesia method in cesarean section is determined according to the urgency of the procedure, the patient's current systemic problems, the request of the patient and the surgeon, and the experience of the anesthesiologist (3). In recent years, especially regional techniques have been used. Regional anesthesia has the advantages of patient comfort, the mother is awake and sees the baby at the time of birth, the fetus is not exposed to inhalation and intravenous anesthetics, and allows pain control after surgery. General anesthesia creates less hypotension and better cardiovascular stability by providing airway and respiratory safety with rapid induction in emergency procedures. However, it should be kept in mind that complications such as aspiration of gastric contents, failure of intubation, maternal hyperventilation, neonatal depression and bleeding due to uterine atony may occur during general anesthesia $(4,5)$.

Nowadays, multiple pregnancy rates are increasing significantly due to the prevalence of assisted reproductive techniques. Since the physiological changes resulting from multiple pregnancies are different from singleton pregnancy, they are considered high-risk pregnancies. Some complications may occur in the prenatal period due to the increase in preterm delivery and the increase in the rate of maternal beta agonist use. Drugs used in multiple pregnancies may cause maternal tachycardia, hypokalemia and pulmonary edema. Multiple pregnancies increase the rate of cesarean delivery and intraoperative complications such as postpartum hemorrhage and hysterectomy.

Regional anesthesia, which is also preferred in twin pregnancies, may lead to more maternal hypotension, which may result from aortocaval compression, especially when compared to singleton pregnancy. However, some patients who have contraindications for regional anesthesia such as thrombocytopenia, coagulopathy or pulmonary edema may cause anesthesiologists to prefer general anesthesia for these patients.

Maternal risk factors are also high in multiple pregnancies. Anesthesia planning should be done earlier and in a planned manner in multiple pregnancies.

The aim of this retrospective study is to compare the hematology and anesthesia complications in multiple and singleton pregnancies retrospectively and to increase the awareness of anesthesiologists and obstetricians about the complications that may occur during and after cesarean section in twin pregnancies.

\section{Methods}

Our study was carried out by retrospectively scanning the anesthesia forms and files of patients in the American Society of Anesthesiology (ASA) 1-2 group who underwent cesarean section between January 2019 and January 2020 at the University of Health Sciences Turkey, İstanbul Training and Research Hospital Gynecology and Obstetrics Clinic.
The cases were then divided into two groups as multiple $(n=50)$ and singleton $(n=63)$ pregnancies, and the hematological and anesthetic complications were compared between the groups.

Patient's age, gestational week, chorioosinity if twin pregnancy, emergency or elective, anesthesia method applied, whether oxytocin and transamine was administered, whether atony was performed, whether blood products were needed, whether there was a decrease in preoperative postop hemogram values, complications in the mother (hypotension, the development of bradycardia, bleeding, nauseavomiting) has been recorded.

Exclusion criteria; ASA 3-4 patients.

In both groups, $1.5 \mathrm{~mL} / \mathrm{kg}$ of crystalloid fluid was first administered in addition to colloid fluid in hypotension (mean arterial blood pressure below $60 \mathrm{mmHg}$ ) following anesthesia. Ephedrine hydrochloride (5-10 $\mathrm{mg}$; IV) was administered in case of persistence of hypotension.

Patients with bradycardia (heart rate falling below 50 beats per minute) were administered $0.5 \mathrm{mg}$ atropine sulphate IV.

\section{Statistical Analysis}

In the evaluation of the data, besides descriptive statistical methods (mean, standard deviation), Student t-test was used by considering normal distribution in comparison of the groups. Chi-square test was used to determine the statistical significance among the groups with bradycardia, nausea-vomiting and hypotension. Significance levels were determined by finding $p$-values suitable for these tests. $\mathrm{P}<0.05$ was considered significant.

Our study has the permission of the University of Health Sciences Turkey, İstanbul Training and Research Hospital Ethics Committee (decision no: 2175 , date: 07.02 .2020$)$. Since our study was retrospective, written consent could not be obtained from the patients.

\section{Results}

As shown in Table 1, no statistically significant difference was found between age, haematocrit (Hct) values before and after surgery and Hct differences in singleton and twin pregnancies $(p>0.05)$. Pregnancy week of twin pregnancies was found to be statistically significantly lower than singleton pregnancies $(\mathrm{p}<0.05)$.

As shown in Table 2, the bradycardia rate in twin pregnancies was found to be statistically significantly lower compared to singleton pregnancies $(p<0.05)$. There was no difference between the rate of nausea and vomiting in twin and singleton pregnancies $(p=0.9)$. There was no difference between the rate of hypotension in twin and singleton pregnancies $(p=0.26)$. ASA 2 twin pregnancy rate was statistically significantly higher than ASA 2 singleton pregnancies $(p<0.05)$. No statistically significant difference was found between the two groups in the rates of emergency, elective cesarean section and regional, and general anesthesia.

Differences in Hct before and after surgery in monochorionic twin pregnancy $(n=7)$, dichorionic twin pregnancy $(n=43)$ patients are 4.24 $\mathrm{g} / \mathrm{dL}$ and $3.84 \mathrm{~g} / \mathrm{dL}$, respectively. No difference was found between Hct 
differences before and after surgery in monochorionic and dichorionic twin pregnancies $(p=0.24)$. In twin pregnancies, the proportion of patients given additional oxytocic agent was found to be $50 \%$. In singleton pregnancies, the proportion of patients given additional oxytocic agent was $23 \%$.

\section{Discussion}

Studies on the differences in hemodynamic changes during cesarean between twin and singleton pregnancies are insufficient. In our study, as shown in Table 1, no difference was found between preand postoperative Hct rates in twin and singleton pregnancies. Hyperdynamic circulation is more in twin pregnancies than in singleton pregnancies. Left ventricular systolic function and mean arterial pressure in twin pregnancies are affected more than singleton pregnancies after the $20^{\text {th }}$ week (6). In many studies, high maternal cardiac output and low peripheral resistance have been shown in twin pregnancies (7). However, high blood loss is correlated with no difference in expected twin pregnancy, high hemodynamic parameters at the beginning of twin pregnancy reach their lowest level in the middle of pregnancy, and then being equivalent to a single pregnancy (8). This hypothesis was supported by the fact that maternal hemodynamic parameters were found equivalent for each singleton and twin pregnancies during and immediately after cesarean in the study conducted by Lavie et al. (8).

Emergency cesarean brings the risk of blood transfusion. In our study, $67 \%$ of single pregnancies and $70 \%$ of twin pregnancies were caesarean sections in emergency conditions. In the study conducted by Kolås et al. (9), the prevalence of excessive blood loss differed between elective
(2.1\%) and emergency (3.3\%) cesarean deliveries. While maternal factors, chronic maternal diseases, conditions related to pregnancy and birth, placenta previa and transverse arrival are risk factors for blood loss in elective operations, placenta previa, placental abruption, intervention to full cervical dilatation and high body mass index were risk factors for blood loss in emergency operations. Although the rate of emergency cesarean section is higher in twin pregnancies, we think that no statistically significant difference can be detected under favour of the early and planned obstetric approach.

In a study conducted by Blickstein et al. (10), hemoglobin values in the first and second trimester were found to be low in twin pregnancies, no difference was found between hemoglobin values in single and twin pregnancies during the third trimester. In our study, there was no statistically significant difference between age, Hct values before and after surgery and Hct differences in single and twin pregnancies (Table 1). In our study, we believe that the reason for the high rate of use of additional oxytoxic agents in twin pregnancies is increased obstetric complications such as premature birth, placenta previa and detachment placenta.

The most common obstetric complication associated with twin pregnancies is preterm birth. In the literature, this rate has been reported at $50 \%$ and is 12 times higher than single pregnancies (11). In our study, similarly, the week of pregnancy of twin pregnancies is lower than that of single pregnancies. Mikami et al. (12) also found that the week of pregnancy at birth in the twin pregnancy group was statistically significantly lower than in the single pregnancy group.

\section{Table 1. General data of caesarean section patients}

\begin{tabular}{|l|l|l|l|}
\hline & Single pregnancy $(\mathbf{n}=\mathbf{6 3})$ & Twin pregnancy $(\mathbf{n}=\mathbf{5 0})$ & $\mathbf{p}$ \\
\hline Age $($ year) & 27.8 & 30 & 0.20 \\
\hline Preoperation Hct (g/dL) & 33.9 & 32.7 & 0.21 \\
\hline Postoperation Hct (g/dL) & 29.3 & 28.8 & 0.18 \\
\hline Hct difference (g/dL) & 5.3 & 3.83 & 0.18 \\
\hline Pregnancy week & 38.1 & 34.3 & $<0.05$ \\
\hline
\end{tabular}

No statistically significant differences were found between age, Hct values before and after surgery and Hct differences in single and twin pregnancies ( $p>0.05$ ). Pregnancy week of twin pregnancies is statistically significantly lower than single pregnancies $(p<0.05)$. Hct: Hematocrit

Table 2. Anesthesia data of caesarean section patients

\begin{tabular}{|l|l|l|l|}
\hline & $\begin{array}{l}\text { Single pregnancy } \\
(\mathbf{n = 6 3 )}(\%)\end{array}$ & $\begin{array}{l}\text { Twin pregnancy } \\
(\mathbf{n = 5 0 )}(\%)\end{array}$ & $\mathbf{p}$ \\
\hline ASA 1 & $18(28 \%)$ & $8(16 \%)$ & $>0.05$ \\
\hline ASA 2 & $45(72 \%)$ & $42(84 \%)$ & $>0.05$ \\
\hline Emergency caesarean section & $42(67 \%)$ & $35(70 \%)$ & $>0.05$ \\
\hline Elective caesarean section & $21(33 \%)$ & $15(30 \%)$ & $>0.05$ \\
\hline Regional anesthesia & $51(80 \%)$ & $43(86 \%)$ & $>0.05$ \\
\hline General anesthesia & $12(28 \%)$ & $7(14 \%)$ & $>0.05$ \\
\hline Nausea-vomiting & $30(47 \%)$ & $25(50 \%)$ & $>0.05$ \\
\hline Hypotension & $42(66 \%)$ & $30(60 \%)$ & $>0.05$ \\
\hline Bradycardia & $32(50 \%)$ & $7(14 \%)$ & $>0.05$ \\
\hline
\end{tabular}

In twin pregnancies, ASA 2 score was statistically significantly higher than single pregnancies and bradycardia rate was statistically significantly lower than single pregnancies ( $<<0.05)$, ASA: American Society of Anesthesiology 
Although spinal anesthesia is generally accepted as safer and appropriate in multiple pregnancies (13), they are more prone to severe hypotension than patients with singleton pregnancy in the literature $(14,15)$. In our study, contrary to the literature, no difference was found between the rate of hypotension in twin and singleton pregnancies (Table 2). Although it seems surprising that our results differ from the literature, in fact, there are very few data supporting the severity of hypotension in multiple pregnancies when the literature is searched. Although Jawan et al. (16) found more cephalic spinal anesthesia spread in twin pregnancies; they found the incidence of hypotension similar to that of singleton pregnancies. Similar to our study, Ngan Kee et al.'s (17) study revealed that there was no difference between single and multiple pregnancies in terms of hypotension, vasopressor need, nausea and vomiting in cesarean deliveries undergoing spinal anesthesia. They concluded that although aortocaval compression is higher in multiple pregnancies, its effect may decrease as the blood volume and cardiac output are increased more, and there is no potential for more hypotension development in multiple pregnancies compared to singleton pregnancies (17). In a study conducted by Behforouz et al. (18), epidural anesthesia was applied to 2 quadruplet, 19 triplet and 31 singleton pregnancies, and the incidence of developing hypotension was found to be similar in singleton and multiple pregnancies. It was observed that the need for Ringer's lactate and total dose of ephedrine was higher in singleton pregnancies with the initiation of the block. This is due to the decreased risk of hypotension due to the increase in blood volume and cardiac output more in multiple pregnancies than singleton pregnancies.

In our study, the rate of bradycardia was found to be statistically high in singleton pregnancies (Figure 1). Bradycardia is caused by sympathetic blockade. The blockade of cardiovascular fibers from T1 to T4 is part of the bradycardia trigger mechanism. In parallel with our results, Pereira et al. (19) found that the rate of development of sinus bradycardia was higher in ASA 1 patients. We think that this can be explained by the high rate of ASA 2 twin pregnancy patients in our study. Since there was no statistically significant difference in the rates of hypotension of our patients, there was no statistically significant difference in the rate of nausea-vomiting between the groups, as expected.

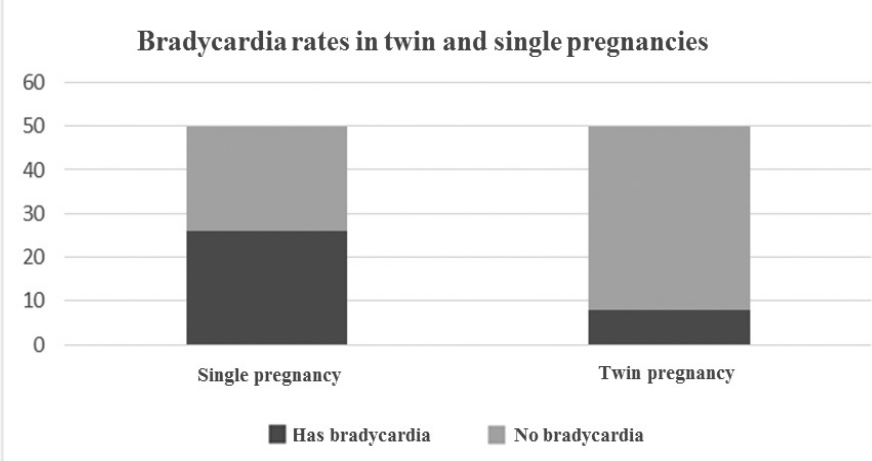

Figure 1. Bradycardia rates in twin and singleton pregnancies A statistically significant difference was found between bradycardia rates in twin and single pregnancies $(p<0.05)$

\section{Conclusion}

In cesarean sections, spinal anesthesia is the preferred anesthesia technique due to its rapid onset of action, reliability, superior postoperative pain control and lower mortality rates when compared with general anesthesia. However, it is predicted that the most important complication is maternal hypotension, which may result from more aortocaval compression in multiple pregnancies, especially when compared with singleton pregnancies.

In Turkey and around the world, studies on the incidence of complications associated with anesthesia in patients with multiple pregnancies delivered by cesarean section are still insufficient. In our study, we identified the complications that may arise from postpartum anesthesia techniques. Based on our data, we recommend that anesthesiologists and obstetricians work as a team and prepare for the operation in a planned and ready manner, considering the hemodynamic changes due to twin pregnancies.

\section{Ethics}

Ethics Committee Approval: The study was approved by the Ethics Committee of the University of Health Sciences Turkey, İstanbul Training and Research Hospital Ethics Committee (decision no: 2175, date: 07.02.2020).

Informed Consent: The study was retrospective, written consent could not be obtained from the patients.

Peer-review: Externally peer-reviewed.

Authorship Contributions: Surgical and Medical Practices - B.S.K.; Concept - B.S.K.; Design - N.A.; Data Collection or Processing - A.G.F.; Analysis or Interpretation - N.A.; Literature Search - B.S.K.; Writing - B.Ş.K.

Conflict of Interest: No conflict of interest was declared by the authors.

Financial Disclosure: The authors declared that this study received no financial support.

\section{References}

1. Gori F, Pasqualucci A, Corradetti F, Milli M, Peduto VA. Maternal and neonatal outcome after cesarean section: the impact of anesthesia. J Matern Fetal Neonatal Med 2007; 20: 53-7.

2. Liu S, Liston RM, Joseph KS, Heaman M, Sauve R, Kramer MS. Materna mortality and severe morbidity associated with low-risk planned cesarean delivery versus planned vaginal delivery at term. CMAJ 2007; 176: 455-60.

3. Şener EB, Güldoğuş F, Tür A, Şahinoğlu H, Kocamanoğlu S. Sezaryende epidural ve genel anestezinin anne konforu yönünden karşılatırılması. Anest Der 2001; 9: 195-9.

4. Gomar C, Fernandez C. Epidural analgesia anaesthesia in obstetrics. Eur J Anaest 2000; 17: 542-58.

5. Fishburne Jr Jl. Obstetrik anestezi ve analjezi. Danforth's Obstetrik ve Jinekoloji. Scott JR, Disaia PJ, Hammond CB, Spellacy WN, editors. 7th edition. Translation: Erez S, Erez R. İstanbul: JB Lippincott Comp \& Yüce Yayım AȘ; 1997.p.129-45.

6. Kametas NA, McAuliffe F, Krampl E, Chambers J, Nicolaides KH. Maternal cardiac function in twin pregnancy. Obstet Gynecol 2003; 102: 806-15.

7. Kuleva M, Youssef A, Maroni E, Contro E, Pilu G, Rizzo N, et al. Maternal cardiac function in normal twin pregnancy: a longitudinal study. Ultrasound Obstet Gynecol 2011; 38: 575-80. 
8. Lavie A, Ram M, Lev S, Blecher Y, Amikam U, Shulman Y, et al. Maternal hemodynamics in late gestation and immediate postpartum in singletons vs. twin pregnancies. Arch Gynecol Obstet 2018; 297: 353-63.

9. Kolås T, Øian P, Skjeldestad FE. Risks for peroperative excessive blood loss in cesarean delivery. Acta Obstet Gynecol Scand 2010; 89: 658-63.

10. Blickstein I, Goldschmit R, Lurie S. Hemoglobin Levels During Twin vs. Singleton Pregnancies. Parity Makes the Difference. J Reprod Med 1995; 40: 47-50.

11. Cruz AC. İkiz gebelik. In: Zuspan FB, editor. Current Therapy in Obstetrics and Gynecology. 4th ed. (çev. ed. Güner H). Ankara: Atlas Tic. AS; 1995.p.391-7.

12. Mikami Y, Takai Y, Era S, Ono Y, Saitoh M, Baba K, et al. Differences in home blood pressure and pulse rates between singleton and twin pregnancies. I Int Med Res 2018; 46: 1496-504.

13. Marino T, Goudas LC, Steinbok V, Craigo SD, Yarnell RW. The anesthetic management of triplet cesarean delivery: a retrospective case series of maternal outcomes. Anesth Analg 2001; 93: 991-5.

14. Gorman Maloney SR, Levinson G. Anesthesia for abnormal positions and presentations, shoulder dystocia, and multiple births. In: Hughes SC, Levinson
G, Rosen MA, editors. Anesthesia for obstetrics. Philadelphia: Lippincott Williams and Wilkins; 2002.p.287-95.

15. Koffel B. Abnormal presentation and multiple gestation. In: Chestnut DH, editor. Obstetric anesthesia. St. Louis: Mosby; 1999.p.694-710.

16. Jawan B, Lee JH, Chong ZK, Chang CS. Spread of spinal anaesthesia for caesarean section in singleton and twin pregnancies. Br J Anaesth 1993; 70: 639-41.

17. Ngan Kee WD, Khaw KS, Ng FF, Karmakar MK, Critchley LA, Gin T. A prospective comparison of vasopressor requirement and hemodynamic changes during spinal anesthesia for cesarean delivery in patients with multiple gestation versus singleton pregnancy. Anesth Analg 2007; 104: 407-11.

18. Behforouz N, Dounas M, Benhamou D. Epidural anaesthesia for caesarean delivery in triple and quadruple pregnancies. Acta Anaesthesiol Scand 1998; 42: 1088-91.

19. Pereira ID, Grando MM, Vianna PT, Braz JC, Castiglia YM, Vane LA, et al. Retrospective analysis of risk factors and predictors of intraoperative complications in neuraxial blocks at Faculdade de Medicina de BotucatuUNESP. Rev Bras Anestesiol 2011; 61: 568-81. 